\title{
THE ROLE OF THE VILLAGE IN FOREST MANAGEMENT: HUMAN RIGHTS PERSPECTIVES
}

\author{
Mohamad Rif'an, Hary Setiawan, Adam Wisnuaji \\ Faculty of Law Brawijaya University \\ Email: assasinalfhabet47@gmail.com
}

\begin{abstract}
1945 opening noble nation Indonesia is an agreement to live together (modus vivendi) in bonding the plural nation. The Modus Vivendi, has given birth to the state's objective, which is the nation's identity and guidelines in their stride. Thus, the constitution has mandated the State to be responsible for the welfare of the people. Indonesia has the second largest tropical forest in the world with high economic value that can be managed by the state and society. This allows for the utilization of various types of plants and economic aspects of the utilization of forest products. In preparation result is a pity forests is not optimal either with intensive and with many requests deforestation or forest land conversion. Deforestation well planned and unplanned forest. On the other hand, Indonesia which acknowledges the existence of the village government and the empowerment of the rural community empowerment which is a process for making the community to improve the quality of life for the better is weak then the need for the existence of the role of government in the village of Village forest management as one of the rights of the villagers. The type of research is normative juridical. Hence this paper initiated a grand design Village forest management to complete the processing and utilization of forest products that are integrated with the role of the village government as a system intended to pengoptimalam supply chain production as one of the important indicators of development and resilience of economies in each region using variable results income forests as principal.
\end{abstract}

Keywords: Industry, Forest, Village, Village Forest Management

\section{INTRODUCTION}

Preamble of Constitrution 1945

is the sublime nation of Indonesia's agreement to live together (modus vivendi) in the bonds of one nation's compound $^{1}$. Modus Vivendi, has given

1 Mahfud MD, Debate Constitutional Law after the amendment of the Constitution, LP3ES, Jakarta, 2007, p. 835). 3-4 birth to the country's ideals, which is the identity of the nation and the guidelines in their stride. ${ }^{2}$ The ideals of the country

2 The purpose of the State of the Republic of Indonesia that is contained in the paragraph IV Opening THE CONSTITUTION NRI Constitution reads " ...to form a State Government of the Republic of Indonesia to protect all the people of Indonesia and all spills blood of Indonesia and to promote the public welfare, educate the life of the nation and 
contained in the preambule of Constitution 1945, shows characteristics of welfare State, which is a characteristic of the modern State. Thus, the Constitution has mandated the state to take responsibility for the welfare of the people. This is reaffirmed in article 33 of the Constitution of 1945 that the land, water, and natural riches contained in it are controlled by the State and used the most for the welfare of the people. This provision then became the foundation of the Constitutional and simultaneously the direction for setting various things related to monopoly arrangements, implementation, usage, supply and maintenance of natural resources as well as setting its legal relations based on a spirit of social, ${ }^{3}$ so the logical consequence that occurs is the placement of the mastery of the resources must be dedicated to the

contribute to the pursuit of a world order based on freedom, lasting peace and social justice..."

${ }^{3}$ In the Article 33 Constitution listed basis economic democracy, production done by all, for all under the direction of or Trainees monitoring members of the community. The prosperity of society is the preferred, not the prosperity of a man. Edi Swasono, Article 33 Constitution must be maintained, Do not changed, be added verse, in a paper, p.30 15. can be accessed at http://webcache.googleusercontent.com/searc h?q=cache:-

WkHKI7iYaYJ:www.bappenas.go.id/index.php /download_file/view/10688+\&cd=7\&hl=en\&ct =clnk\&gl=id, accessed on 7 February 2016 at unfortunately public interest with the principle of fair and just, trustworthy (accountable), and transparent (good governance). ${ }^{4}$

One of the natural resources of the most influential in the Indonesian economy and frequently noted the position of its law is forest. ${ }^{5}$ Indonesia has the second largest tropical forest in the world with high economic value that can be managed by the State and society. The role of the forestry sector in economic growth began in 1967 through the concession of rights of forest Entrepreneurs (HPH). Between the years of 1967 to 1980, 519 companies have been given HPH that includes 53 million hectares. Up to June

4 SF. Marbun, the existence of the general Asas-Asas Proper Governance in manifest Good Governance and clean in Indonesia, Dissertation, not published, postgraduate program Faculty of Law University of Padjadjaran Bandung, 2001. p. 835). 50

${ }^{5}$ The author agree on rahmina opinion that the regulatory framework of legislation in Indonesia for the forestry sector started with UndangUndang 411999 jo Law Number 19 Year 2004 about the Announcement of Government Regulations for replacement of Law Number 1 Year 2004 about the amendment of Act No. 41 The year 1999 about Forestry Act, also related to Law No. 5 The year 1990 about Natural Resources Conservation Biodiversity and Their Ecosystems and implementing regulations under the details of the management of the forest area in accordance with the function and status. Rahmina, elect the scheme of community-based forest management in the mitigation of Climate Change, Jakarta, Deutsche Gesellschaft für internationale Zusammenarbeit (GIZ) GmbH Forests and Climate Change Program (FORCLIME), 2012 page 3 
1998 there were $651 \mathrm{HPH}$ with the allocation of the forest area of 69.4 million hectares. The timber industry and forest products generates US \$ 9 billion in 1994, US \$ 5.5 billion of which are from exports. In the last ten years, foreign exchange contribution of timber industry achieved an average of $20 \%$ of total foreign exchange earnings of Indonesia. Within the framework of legislation, forest management by the public through Regulation of Government (PP) No. 6 of 2007 Jo PP No. 3 in 2008, the scheme concerning forest that accommodated by the state is the Forest of village, community forests , and partnerships, in addition to the three schemes, there are also other schemes that are set in the regulation of the Minister of Forestry such as the Forest of the people, Joint management of forest, and Forest Plantation of Communities. This explains that the management of the forest products with the goal of economic must see the kind of forest that will be processed to minimize forest exploitation without considering the impact that occurred on the environment. ${ }^{6}$

\footnotetext{
Humas Ment

Kuansing, Forest Potential, 2016, accessed at http://www.kuansing.go.id/investasi/sektorkehutanan/, accessed on 8 February 2016 at 23.02
}

Arogonomic conditions support Indonesia as the owner of land resources ${ }^{7}$ for the development of a wide variety of the forest product's commodity. With the land area of Indonesia reaching 188.20 million hectares, or $24 \%$ of the total area that consists of the entire concession in Indonesia $^{8}$, allows for the resurgence of various types of plants and the economic aspects of the utilization of forest products including industrial commodities in large or small industries (Small Medium Enterprises/ UMKM). The condition is inversely proportional with the existence of the forest industry as material procurement of supply chain production, to clarify the standard definition of 'the supply chain', the author quoting on the Hugos statement (2003, 2-3) which provides supply chain definition that "A supply chain consists of all stages involved, directly or

7 Statistical data of the use of agricultural land indonesia 2003 shows that the potential of agricultural land resources in Indonesia is the area of 70.60 million ha. Area of land used for agriculture business reach 53,71 million ha, while that used for agriculture business not reach 16,89 million ha, Anny, Irsal, Resource potential land and Commodity Development Optimization Bioenergy producer in Indonesia, Bogor; R\&D Journal of Agriculture, 2009 page 9

8 The terms of the exterior design of the national territory, 67 million ha (35\%) should be used as a protected area and the rest of the land to be used for the area of aquaculture, ibid, p.30 9 
indirectly, In fulfilling a customer request. The supply chain not only includes the manufacturer and suppliers, but also transporters, warehouses, retailers, and event themselves." (Chopra and Meindl, in the Hugos, 2003, 2). The theoretical foundation of the Hugos is a reflection that the supply chain is the provision of industrial raw materials that can be processed, empowered and coordinated to the consumer. Viewed from some cases that occurred, it is a dilemma when an industry has made forests as the supply chains of production without considering the stability of the environment.

The superiority of Agronomic conditions, especially in the management of forest products still in the status not optimal when reflect on the processing of forest products which is evidenced by the end of 2009, almost half the forest areas in Indonesia (46.5\% or 55.93 million hectares) were not managed with intensive ${ }^{9}$ and with demand deforestation or land of forest conversion. Both the Deforestation that is planned ${ }^{10}$ or unplanned deforestation.

\footnotetext{
${ }^{9}$ Opcit

${ }^{10}$ Is the conversion that occurred in the production forest area which can be converted (HPK) released into the area of aquaculture non forestry (KBNK area or APL). The planned
}

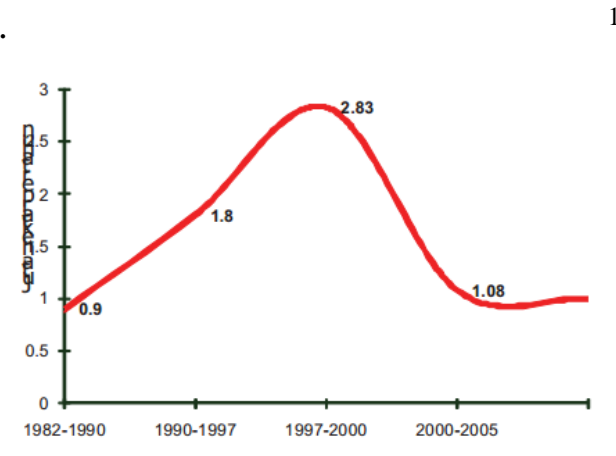

Picture. 1 Deforestation 1982-2005

Refers to the existence of the village development or rural development which is a development scheme to cultivate the development of the community as well as the environment of its life. ${ }^{12}$ The theory gives hope through manifestation of development and empowerment of the village community. Theoretical review on the village community empowerment is a process to make the society or group of weak more empowered with the aim to improve the quality of life of weak community to be better. The existence of this community empowerment will make the society to

conversion can also occur in the area of production forest to open mining. Zulkiflie, Arief, forest issues Indonesia, 2013, accessed at http://bangazul.com/permasalahan-hutan-diindonesia/, accessed on 7 February 2016 at 5.12

${ }^{11}$ unplanned deforestation is due to the conversion of forest that occurs in all areas of the forest as a result of various activities which are not planned, especially illegal activities, ibid.

12 Riwu, Joko, Basic Social Science, Yoyakarta: National Business,1989, p. 835). 212 
has the ability and the power to fulfill basic needs, reach productive resources, allowing them to increase revenue and participate in the development process of the village, so they have freedom, not only freedom of speech, but rather free from poverty and ignorance. In this case, empowerment is inseparable from power (to rule/authority) because there is authority in power, so the main idea of empowerment is in contact with the concept of authority or the village's government. 13 Subject of the environmental review and community development is not separated from the concept of village's management of Assets that has been regulated in Act No. 6 Of the village by 2014. The assets of the village can be the land of the village customary land, cash, market village, animal markets, overnight boat, building villages, fish auction, the auction results of agriculture, forests of the Village, , springs of water belongs to the village, public baths, and other assets belongs to the village. ${ }^{14}$

These problems become a basis for the author to established a

13 Edi Suharto, build community to empower the community, Bandung: Refika Aditama, 2010, p. 835). 58-59

${ }^{14}$ Law of the Republic of Indonesia Number 6 Year 2014 regarding the village Article 76 Paragraph (1)
Greendesign in the processing of forest products intensively, but also to observe the integrity of the stakeholders (Government and society) therein is one of the alternative solutions for the existing issues on the forest processing today. Therefore, the study of the existence of the forest processing in the village which refers to the integrity of the stakeholders is necessary. This type of research is Juridical-normative, i.e. researchers/authors elucidate the legal materials either primary, secondary, or tertiary and 2 (two) methods approach i.e. statutory approach (statuteapproach), by examining the formation of legislation ${ }^{15}$ relating to forest processing and conceptual Approach (conseptual approach), by studying and understanding the required dimensions in the concept of the Village forest management. ${ }^{16}$ The authors hopes that this research is works to improve and serves the program tree bank and following up the program as the repressive actions of the Government on issues concerning land crisis and the lack of intensive processing of forest products in 2009 to successfully enable

\footnotetext{
15 Peter Mahmud Marzuki, Legal Research, Kencana, Jakarta, 2007, p. 835). 96.

16 Johnny Ibrahim, the theory and research methodology of the normative Law, Malang, Bayumedia, 2007, p. 835). 391.
} 
and include the roles of villagers and upholding the rights and welfare of the community development. ${ }^{17}$

This research also aims to find an overview of a system aimed at optimizing the supply chain production in industrial sectors, one of which is the Small Medium Enterprises/UMKM as one of the important indicators of development and the resilience of the economy of the state in every province that uses variable forest products as its main income. Thus we expect that the condition of utilization of the resulting forest can match the development and includes the society. The formulation of the problem:

1. How is the current problems of the Village forest management?

2. How is the concept of the Tree Bank Processing as a supply chain optimization system of production Forest Village?

\section{METHODOLOGY}

This type of research is Juridical-normative, i.e. researchers

17 Deputy Assistant of urban Community Empowerment, Program Bank Pohon Hijaukan Sepuluh Hektar Lahan Kritis Di Kabupaten Bandung, 2006, can be accessed at http://www.menlh.go.id/program-bankpohon-hijaukan-sepuluh-hektar-lahan-kritis-dikabupaten-bandung/, accessed on 9 February 2016 at 9.08 elucidate the legal materials either primary, secondary, or tertiary and 2 (two) methods approach i.e. statutory approach (statute-approach), by examining the formation of legislation ${ }^{18}$ relating to forest processing and conceptual Approach (conseptual approach), by studying and understanding the required dimensions in the concept of the Village forest management. ${ }^{19}$ The authors hopes that this research is works to improve and serves the program tree bank and following up the program as the repressive actions of the Government on issues concerning land crisis and the lack of intensive processing of forest products in 2009 to successfully enable and include the roles of villagers as well as upholding the rights and welfare of the community development of the village.

\section{III.RESULT AND DISCUSSION}

CURRENT PROBLEMS OF FOREST PRODUCT PROCESSING

Attempts to build a community based forest management has been pursued since the 19th century during

18 Peter Mahmud Marzuki, Legal Research, Kencana, Jakarta, 2007, p. 835). 96.

19 Johnny Ibrahim, the theory and research methodology of the normative Law, Malang, Bayumedia, 2007, p. 835). 391. 
the colonial era . Teak forests intercropping policies in Java were excellent examples. This policy was created to address the failure of colonial forestry development policies of forests conservation and resolution of conflict with forest communities . Furthermore, with a variety of models, efforts to build collaborative forest were attempted . The 8th World Forestry Congress themed Forest for People in Jakarta is one of the driving momentum of this policy during the New Order era. Social Forestry Program and a number of cooperation projects abroad for community-based forest management trials were conducted . The famous one is a project carried out in Sanggau , West Kalimantan in cooperation between the Indonesian and the Germany Governments ${ }^{20}$

The legislation framework of Indonesia 's forestry sector begins with Law No. 5 Year 1967 On the Basic Provisions of Forestry, which still valid until 1999 , later repealed and replaced

\footnotetext{
${ }^{20}$ Safitri, Myrna A. Community-based forest management, Forestry conflict and justice over tenure: Opportunities and limitations, in a paper page 6 online, can be accessed at http://acch.kpk.go.id/documents/10180/15308 /sesi3-myrna-safitri-paper-semiloka-kawasanhutan-epistema.PDF/0de3a27e-f9f5-40b0-a2a1a69cd4dbec25, accessed on 7 February 2016 at 6.05, diakses pada 7 Februari 2016 pukul 6.05
}

by Law No. 41 Year 1999 as amended by Law No. 19 Year 2004 concerning the Government Regulation in Lieu of Law No. 1 Year 2004 on the Amendment to Law No. 41 Year 1999 on Forestry to become Law , are also associated with Act No. 5 Year 1990 On Natural Resources and Ecosystem Conservation and implementing regulations under details of forest management in accordance with the function and status. While forest management and community were previously arranged in a series of regulation of the Minister of Forestry , until it is determined in Government Regulation No. 6/2007 Jo PP 3 Year 2008 on Forest Management, Planning and Utilisation. ${ }^{21}$

A fair forest management distribution can be observed from National Forestry Plan ( RKN ) documents 2011-2030 of the Ministry of Forestry . With effective forest area of 112.34 million hectares 43.62 million hectares ( 39 percent ) is allocated to license management for corporations , while the lands designated for the

21 Rahmina, elect the scheme of community-based forest management in the mitigation of Climate Change, Jakarta; Deutsche Gesellschaft für internationale Zusammenarbeit (Giz) Gmbh Forests and Climate Change Program (Forclime), 2012, page 3 
people only amounted to 5.57 million hectares ( 5 percent ) of the effective forest area . Meanwhile, of 88361 total number of villages in Indonesia , about 33957 ( 36.17 percent ) are in , on, or around the outskirt of the forest areas. ${ }^{22}$

Terrible management and utilization of forests in Indonesia for all this years has been causing damage to Indonesia's forests which are difficult to rehabiliate in a short time. In the 1970 Indonesian forest area reached 143 million hectares, assuming $70 \%$ vegetated woods, this means that there were 100 million hectares of forest . However, now this status had deteriorated dramatically at an alarming pace, with only 21.4 million hectares of vegetated forest area currently left . The 1997 study of the conservation of forests that occur at; protected forest ( less than 25 million hectares ), forest conservation ( 15 million hectares), production forest ( 25 million hectares ) and limited production forest ( 25 million hectares). ${ }^{23}$

22 Perhutani, Reports of National Forum for the forest and the community of community-based Forest Management the status of the present and the future of the Jakarta 15 16 April 2014, Bangkok ; RECOFTC, 2014, p.30 26

23 Fox, J., M. Wasson and G. Applehate. 2000. Forest Use Policies and Strategies in Indonesia: A Need for Change.
In the case of natural forests , the author takes a sample of Indonesian mangrove forest area which continues to decline with each passing years . According to the FAO (1982), Indonesia mangrove forest area in 1982 were approximately 4.25 million hectares . In 1987 mangrove forest area has been reduced to 3.24 million ha and at 1995 survey results, the area decreased again to 2.06 million ha. According to Data from the Indonesia Ministry of Forestry mentions there is only about 1.71 million ha $\mathrm{N}$ of mangrove forest left ${ }^{24}$. A second sample occurred in 2002 , Kampar Peninsula forest were mostly untouched from 700,000 hectares in 2007, which consist of about 300,000 hectares of wetlands ( $37 \%$ of the area of origin ) have been encroached, drained and/or burned ${ }^{25}$ to fulfill the needs of tropical timber from pulp mills industry and provide land for

Jakarta. The paper presented to the World Bank May 2000

${ }^{24}$ Arif, A. Mangrove Forest functions and benefits. Yogyakarta; Kanisius. 2003 p.30 13

25 Eyes on the forest report, March 2008 Eyes on the Forest to Asia Pulp \& Paper: Cease all destruction of one of the world's largest tropical peatland forests - Kampar Peninsula in Riau Province, Sumatra Indonesia, can be accessed at assets.panda.org/.../eof_news_on_app_in_ka mpar_final_english_25mar08_1., p.30 2. Access ed on January 222016 at 04.32 
plantations ${ }^{26}$ acacia $^{27}$ for palm oil. Only

$10 \%$ of the remaining intact peatlands are officially protected , while the $90 \%$ of other peatland area is strongly threatened by HTI (Hutan Tanaman Industri/Industrial vegetation forest) development of pulp and paper company. ${ }^{28}$

Not only in the condition of the forest, but unconstitutional condition were also occuring in forest products converters issue at 2007 by the company APP, which was known to have repeatedly bought illegal timber originating from peatlands in Riau province . Despite the peat depth in this region exceeds 4 meters, which means it illegal to be encroached , developed or dried under Indonesian law. ${ }^{29}$ These

${ }^{26}$ The plantation is not natural forest. Natural forests have various kinds of trees and into the place of his life all kinds of plants and animals. On the contrary, plantation often have only one species of trees with the same age and planted near. They do not support the life of animals and have the level of clean water is low. These trees also store carbon in the amount lower than the natural forest. The definition of UNFCCC will be "forests" not differentiate natural forests with plantations - but this is absolute. Novice,John, Indonesian Tropical Forests and climate crisis, Jakarta; Okini, 2010, page 5

${ }^{27}$ Ibid, p.30 5

28 Miettinen, Otto, Kampar Peninsula as a peat swamp forest conservation priority Briefing for NGO, in a paper, accessed at http://www.maanystavat.fi/april/resourcesforka mpar2007/Miettinen2007longKamparPeninsula. Pdf, Accessed on 10 February 2016 at 7.46

${ }^{29}$ Ministry of Agriculture Indonesia (2009) Ministerial Decree (Regulation of the conditions were also continued in a subsidiary of APP, Indah Kiat which runs pulp mills industry in Indonesia , with a capacity of 2 million tonnes of pulp per year . In 2000 it was discovered that $75 \%$ of timber resources of the company come from deforestation. ${ }^{30}$ In 2005 , both of the pulp mills of APP ( Indah Kiat and Lontar Papyrus ) fulfilled $60 \%$ of the their wood fiber demand through natural forest timber and not from their HTI. $^{31}$

VILLAGE FORRESTRY MANAGEMENT THROUGH TREE BANK

\section{A. Existance of Tree Bank program}

\begin{tabular}{|c|c|}
\hline Agriculture & No \\
\hline $\begin{array}{l}\text { 14/Permentan/OT.110/2/2009; } \\
\text { Decree No 32/ of } 25 \text { July } 1990\end{array}$ & Presidential \\
\hline
\end{tabular}
Matthew (2001), in a paper, can be accessed at www.foe.co.uk/resource/reports/paper_tiger hidden_dragons.pdf, accessed on February 11 2016 at 10.01

$31 \quad$ Clashed Physically, 500 police personnel forced Pricks Suluk Bongkal citizens, 19 December 2008, http://www.kompas.com/read/xml/2008/12/19/0 0365789/bentrok.fisik.500.personil.polisi.usir. force.host.suluk.bongkal.This article is unavailable in English. The information in this briefing is an on this man of the article. For further reference refer to Jakarta Post Riau Police guilty of human rights abuses: Komnas HAM, 30 December 2008. Can be accessed at http://www.thejakartapost.com/news/2008/12 /30/riau-policeguilty-rights-abuses-komnasham.html, accessed on February 112016 at 14.01 
It has been explained in the introduction that the tree bank program were conducted as a repressive action of the government in matters concerning land crisis and the lack of intensive processing of forest products in 2009 which successfully enabled and include the role of rural communities by utilizing forest village. ${ }^{32}$

\section{B. Procurement of Village Forest as the Main Asset of Tree Bank}

Village Forest is a state forest which managed by the village, used for wellness of the village, carried out in protected forest areas and productive forest,is not burdened with management rights or exploitation permit, forest management rights village consists of Right Management , IUPHHK , IUPK , IUPJL , IUPHHBK , IPHHK , IPHHBK which was not limited by term because it is determined by the village itself through village forest management institutions that established and defined by village's regulations, except IUPHHK which

32 Deputy Assistant of urban Community Empowerment, Program Bank Pohon Hijaukan Sepuluh Hektar Lahan Kritis Di Kabupaten Bandung, 2006, can be accessed at http://www.menlh.go.id/program-bankpohon-hijaukan-sepuluh-hektar-lahan-kritis-dikabupaten-bandung/, accessed on 9 February 2016 at 9.08 follow the provisions of article $49 \mathrm{~s} / \mathrm{d}$ 59 PP 6 Year 2007 Jo PP . 3 of 2008 and completed in the second amendment of Regulation p.49 / 2008 to Ministrial Decree No. P.14 / 2010. ${ }^{33}$ Said sequence is then refined by P.53 / 2011 of Forest Village that replace the entire Article 6 becomes: UPT Directorate of Watershed Management and Social Forestry authority to coordinating with UPT Echelon I Ministry of Forestry and Local Government to determine the prospective areas and facilitate the establish village forest village institutions, to make HPHD petition to the governor with a copy to the Regent / Mayor. But in any other areas outside the area nominated by UPT DAS, local communities can apply for the establishment of village forest production area to the Regent / Mayor. Request filed by the village chief to the Regent / Mayor to include petitioned location sketches; The proposal letter from the Village Head / Lurah; The names of candidates for village organizations or institutional structures if already formed village which is

33 The presentation of the Ministry of Forestry in learning workshop Implementation of village forest in East Kalimantan, March 2011 
already known by the sub-district and village chief / Lurah; according to said request then regent / mayor will complete it with a digital map of the prospective area of Productive forest , description of the area (physical, social, and economic potential of the region, the proposed letter from the Village Head / Lurah and names of the candidates or the institutional structure of the village if it is already exists. All of previously mentioned documents becomes the proposal for the establishment of production forest area for the Minister of forrestry. Also during the nomination process, the Governor or Regent / Mayor facilitate the establishment and improvement of that village's institutions. ${ }^{34}$

Essentially the filling procedure for village's Trees Bank is similiar to filling IUPHHK license in Forest Village, although there are some modifications such as follows :

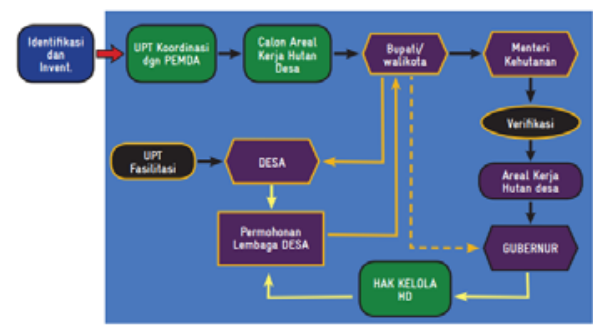

Picture 2: The Village Forest Procurement Flow

34 The explanation about Permenhut No. P. 49/Menhut-II/2008 about Village Forest
1. The proposal is submitted by the Village to the Regent / Mayor which will forwarded the letter to the Governor;

2. Proposed followed by Regents / Mayors to the Minister of environment and forestry,

3. Establishment of Trees Bank Village area is done by the Minister of environment and Forestry

4. Provision of manpower, Trees Bank Management Unit and Environmental Conditions Management Unit

5. Establishment of management type in the Trees Bank is done after the calculation of the forest's potential and condition from the Ministry of Environment and Forestry by the Governor

6. Utilisation of Timber and forest products can be done at Forest Village that serves as Production Forest through the Trees Bank business license granted by the Ministry of Environment and Forestry ,which can be delegated to the Governor for the Natural Forest, and regent for Planted 
Forests

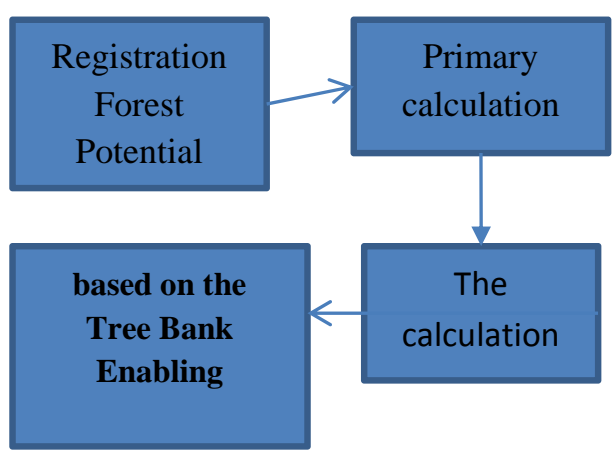

Picture. 3 The procurement flow types of potential Tree Bank

Village Forest Management is a new system that utilizes traditional practices of land utillisation which elements consist of :

a. Land use or land use by humans

b. Application of technology

c. Components of annual crops and perennial crops.

d. Can be done either simultaneously or in turns in a given period

e. Interaction between ecological, social, and economical aspects. ${ }^{35}$

i. Production Supply Chain On Small Industries Through Trees Bank

35

Hairiah, Dkk, Introduction Argoforestry Mingled, Bogor; World Agroforestry Center ICRAF), 2003, p.30 33 ii. The use of Village Forest Management above is an accesoir for the mapping of Production Supply Chain which supports the Forest Products Industry capabilities to compete on selected markets. Each Trees Bank that cultivated by the village will have the characteristics and diverse supply of trees considering the condition of Indonesia's various Agronomy

.Supported by accumulated funds of tree cultivation and forest growing value calculation provides the potential to Trees Bank to adjust the demand and long term availability of forest product 


\section{IV.CONCLUSION}

The development of forest products is one of the issues that need special attention. The sector of forestry has not been managed intensively. In addition, problems of supervision and customs of the society and legal entities involved in the processing of forest products that are less put forward environmental conditions had became one of the causes of suboptimal product development forest products. A Bank of trees is the most suitable body to develop the potential of the village. A Bank of trees will not develop if human resources, manage it less qualified, necessitating the role stakeholders and support the village rich in ideas so it is easier to do invention and innovation in the forestry sector.

To realize the optimization of the supply chain of production in the industrial sector. product development in forest products through re-existence of coral Trees in the village Bank, it takes harmonious collaboration between villagers and the Government as a result of forest products development in the village. In realizing the harmonious collaboration, because it is the concept of Village forest management as the system optimisation of existing the
Bank of trees is very necessary. Thus, it is recommended that:

1. The need for study of Bank regulation on the back of the tree and hold updates rules on a Bank of trees.

2. The refinement of the system on a concept of Village forest management is indispensable for tackling the potential void of legal and technical problems in the operations of a Bank of trees.

\section{REFERENCE}

\section{BOOK}

Antonio, Safii, 2007, Muhammad, sharia banks from the theory into practice, Jakarta; Gema Insani

Arif, A, 2003. Mangrove Forest functions and Benefits. Yogyakarta; Kanisius.

Ibrahim, Johnny, 2007, the theory and research methodology of the normative Law, Malang, Bayumedia
Kurniatun Hairiah, et al, 2003, Introduction Argoforestry Mingled, Bogor; World Agroforestry Center ICRAF)

Mahfud MD, 2007, Debate Constitutional Law after the amendment of the Constitution, LP3ES, Jakarta 
Mahmud, Peter M, 2007, Legal Research, Kencana, Jakarta

Moh Nazarite, 2005, Research Method, Ghalia Indonesia, Jakarta

Novice,John, Indonesian Tropical Forests and climate crisis, Jakarta; Okini, 2010.

Perhutani, 2014, Reports of National Forum for the forest and the community of community-based Forest Management the status of the present and the future of the Jakarta 15 - 16 April 2014, Bangkok ; RECOFTC

Rahmina, 2012, elect the scheme of community-based forest management in the mitigation of Climate

Change, Jakarta, Deutsche Gesellschaft für internationale Zusammenarbeit (GIZ) $\mathrm{GmbH}$ Forests and Climate Change Program (FORCLIME).

SF. Marbun, 2001, the existence of the general Asas-Asas Proper Governance in manifest Good Governance and clean in Indonesia, Dissertation, not published, post-graduate program Faculty of Law University of Padjadjaran Bandung,

\section{JOURNAL}

Abdullah Abidin, S.E. crowned Business development of micro small and medium enterprises
(Msmes) As strategic strength in Accelerate Regional Development, in a paper

Akhmad Fauzi, Alex Oxtavianus, 2014, The Chaired of Sustainable Development in Indonesia , The Journal of Economic Development, Bogor, IPB Press.

Anny, Irsal, 2009, Resource potential land and Commodity Development Optimization Bioenergy producer in Indonesia, Bogor; R\&D Journal of Agriculture

Clashed Physical, 500 police personnel forced Pricks Suluk Bongkal citizens, 19 December 2008, http://www.kompas.com/read/x $\mathrm{ml} / 2008 / 12 / 19 / 00365789 /$ bentro k.fisik.500.personil.polisi.usir. force.host.suluk.bongkal.This article is unavailable in English. The information in this briefing is an on this man of the article. For further reference refer to Jakarta Post Riau Police guilty of human rights abuses: Komnas HAM, 30 December 2008. Can be accessed at http://www.thejakartapost.co $\mathrm{m} /$ news/2008/12/30/riaupoliceguilty-rights-abuseskomnas-ham.html, accessed on February 112016 at 14.09

Eyes on the forest report, March 2008 Eyes on the Forest to Asia Pulp \& Paper: Cease all destruction of one of the world's largest tropical peatland forests Kampar Peninsula in Riau Province, Sumatra Indonesia, can be accessed at assets.panda.org/.../eof_news_ 
on_app_in_kampar_final_englis h_25mar08_1., p.30 2. Accessed on January 222016 at 04.32

Fox, J., M. Wasson and G. Applehate. 2000. Forest Use Policies and Strategies in Indonesia: A Need for Change. Jakarta. The paper presented to the World Bank May 2000

Friends of the earth, Ed Matthew (2001), in a paper, can be accessed at www.foe.co.uk/reso urce/reports/paper tiger hidden _dragons.pdf, accessed on February 112016 at 10.01

Handoko, et al, 2012, Identification stages and Social Infuenced Forest Development of the people in the vicinity of the protected forest area (Stages And Social Factors Identification On The Development of Private Forest Around Protection Forest), The Journal of Forest Research Wallacea Vol.1 No.2

The Ministry of Forestry, 2013, statistics of the Ministry of Forestry Ministry of Forestry Statistics 2013. Jakarta; the Forestry Ministry, p.30 18

The Ministry of Forestry, statistics of the Ministry of Forestry Ministry of $\quad$ Forestry Statistics 2013. Jakarta; the Forestry Ministry

Manzini, Dkk. (2005). The simulation performance in the optimization of the supply chain. The Journal of Manufacturing Technology Management
Miettinen , Otto, Kampar Peninsula as a peat swamp forest conservation priority Briefing for NGO, in a paper, accessed at http://www.maanystavat.fi/april/ resourcesforkampar2007/Miettin en2007longKamparPeninsula. Pdf, Accessed on 10 February 2016 at 7.46

The presentation of the Ministry of Forestry in learning workshop Implementation of village forest in East Kalimantan, March 2011

Safitri, Myrna A.Community-based forest management, Forestry conflict and justice over tenure: Opportunities and limitations, in a paper page 6 online, can be accessed

at http://acch.kpk.go.id/documen ts/10180/15308/sesi3-myrnasafitri-paper-semiloka-kawasanhutan-epistema.PDF/0de3a27ef9f5-40b0-a2a1-a69cd4dbec25, accessed on 7 February 2016 at 6.05

Edi Swasono, Article 33 Constitution must be maintained, Do not changed, be added verse, in a paper, can be accessed at http://webcache.googleuserco ntent.com/search?q=cache:WkHKI7iYaYJ:www.bappenas. go.id/index.php/download_file/v $\underline{\text { iew } / 10688+\& \mathrm{~cd}=7 \& \mathrm{hl}=\text { en } \& \mathrm{ct}=\mathrm{c}}$ lnk\&gl=id, accessed on 7 February 2016 at unfortunately

Invite the gift, Dkk, the development of critical land, in a paper, online http://www.litbang.pertan ian.go.id/buku/membalikkecenderungan-degrad/BAB-IV1.pdf, accessed on 9 February 2016 at 11.54 
Zulkiflie, Arief, forest issues Indonesia, 2013, accessed at http://bangazul.com/permasal ahan-hutan-di-indonesia/, accessed on 7 February 2016 at 5.12

\section{ACT}

The Constitution of the State of the Republic of Indonesia 1945;

Act No. 5/ 1990 About Natural Resources Conservation Biodiversity and Their Ecosystems.

Act No. 41 Tahun 1999 About Forestry.
Act No.19 Tahun 2004 About the Announcement of Government Regulations for replacement of Law Number 1 Year 2004 about the amendment of Act No. 41 The year 1999 About Forestry Act.

Act No. 18 Tahun 2013 About the prevention and eradication of forest destruction.

Decision of Constitutional Court No. 35/Puu-X/2012.

The Government Regulation No. 6/2007 Jo PP 3 Years 2008 about forest governance and planning, Forests and Forest Utilization 